\title{
Structure and Reactivity of a High-Spin, Non-Heme Iron(III)- Superoxo Complex Supported by Phosphinimide Ligands
}

\author{
Charles Winslow ${ }^{\dagger}$, Heui Beom Lee ${ }^{\dagger}$, Mackenzie J. Field ${ }^{\ddagger}$, Simon J. Teat ${ }^{\S}$, and Jonathan \\ Rittle $e^{\dagger, *}$ \\ $\dagger$ College of Chemistry, University of California Berkeley, Berkeley, California 94720, United States \\ ‡ Department of Chemistry, University of California Irvine, Irvine, California 92697, United States \\ $\S$ Advanced Light Source, Lawrence Berkeley National Laboratory, Berkeley, California 94720, United States
}

\begin{abstract}
Non-heme iron oxygenases utilize dioxygen to accomplish challenging chemical oxidations. Further understanding of the $\mathrm{Fe}-\mathrm{O}_{2}$ intermediates implicated in these processes is challenged by their highly transient nature. To that end, we have developed a ligand platform featuring phosphinimide donors intended to stabilize oxidized, high-spin iron complexes. $\mathrm{O}_{2}$ exposure of single crystals of a three-coordinate $\mathrm{Fe}(\mathrm{II})$ complex of this framework allowed for in crystallo trapping of a terminally-bound $\mathrm{Fe}_{2} \mathrm{O}_{2}$ complex suitable for XRD characterization. Spectroscopic and computational studies of this species support a high-spin Fe(III) center antiferromagnetically coupled to a superoxide ligand, similar to that proposed for numerous non-heme iron oxygenases. In addition to the stability of this synthetic Fe$\mathrm{O}_{2}$ complex, its ability to engage in a range of stoichiometric and catalytic oxidation processes demonstrates that this iron-phosphinimide system is primed for development in modelling oxidizing bioinorganic intermediates and green oxidation chemistry.
\end{abstract}

\section{Introduction}

Dioxygen is the ideal chemical oxidant. ${ }^{1}$ Enzymatic systems that effectively harness $\mathrm{O}_{2}$, such as the large class of mononuclear non-heme iron oxygenases, are essential to myriad biological processes. ${ }^{2}$ This particular class of enzymes catalyze an enormous range of $\mathrm{O}_{2}-$ dependent substrate oxidations that are increasingly recognized to proceed via pronounced mechanistic diversity. ${ }^{3}$ Perhaps the only chemical events central to all of these enzymes is the coordination and activation of $\mathrm{O}_{2}$ by the iron cofactor. Yet, discrete $\mathrm{Fe}-\mathrm{O}_{2}$ intermediates have proven to be highly transient or unobservable in most enzymes. ${ }^{4-6}$ Moreover, synthetic examples of wellcharacterized, non-heme $\mathrm{Fe}-\mathrm{O}_{2}$ complexes remain scarce owing to their reactive nature..$^{7-9}$

These enzymes have inspired numerous breakthroughs in the creation of synthetic catalysts for sustainable oxidation processes. ${ }^{10-12}$ Molecular catalysts for selective $\mathrm{C}-\mathrm{H}$ bond functionalization, alcohol oxidation and alkene epoxidation have been developed that possess structural and/or mechanistic features congruent with those of non-heme iron enzymes. ${ }^{10}$ However, unlike the natural systems, most of these synthetic catalysts do not utilize $\mathrm{O}_{2}$ directly and instead rely upon alternative oxidants - such as peroxides - which provide access to viable catalytic intermediates at the expense of increased cost or undesirable side reactivity. ${ }^{13}$ Understanding and developing molecular systems that directly harness $\mathrm{O}_{2}$ as a reagent could enable transformative advances in chemical oxidation catalysis.

We have initiated a research program that aims to develop new molecular catalysts for sustainable oxidative processes. Along these lines we have developed an electron-donating and oxidatively-resilient ligand platform featuring anionic phosphinimide donors intended to expand the reaction chemistry of Earth-abundant, firstrow transition metals. ${ }^{14}$ Herein, we show that this ligand enables the synthesis and characterization - including the $\mathrm{XRD}$ analysis - of a non-heme iron complex that binds $\mathrm{O}_{2}$ in a terminal fashion. The available structural, spectroscopic, and computational data on this species corroborates a high-spin iron(III)-superoxide formulation which, in turn, is active in a diverse array of oxidation reactions, including catalytic $\mathrm{O}_{2}$-mediated aldehyde deformylation.

\section{Results and Discussion}

Terminally-bound phosphinimides are weak-field, $\pi$ basic ligands isolobal to alkoxides. ${ }^{15}$ They have most commonly been used to stabilize electron-deficient lanthanides and early transition metals. ${ }^{16,17}$ In contrast, the coordination chemistry of these ligands with transition metals harboring substantial $d$-electron counts has not been intensively studied, owing in part to the propensity of phosphinimides to instead act as bridging ligands with electron rich metals. ${ }^{18,19}$ The ligand platform employed here features a rigid, sterically-encumbering framework designed to preclude oligomerization and direct these ligands to a single metal ion. Scheme 1 details an abbreviated synthesis of our featured tris(phosphinimine) pro-ligand $\left(\mathrm{L}^{\mathrm{Ad}} \mathrm{H}_{3}\right)$ decorated with bulky 1-adamantyl substituents.

The $\mathrm{L}^{\mathrm{Ad}} \mathrm{H}_{3}$ pro-ligand supports an electron-rich mononuclear $\mathrm{Fe}(\mathrm{II})$ species. The combination of $\mathrm{Fe}(\mathrm{HMDS})_{2}$ with $\mathrm{L}^{\mathrm{Ad}} \mathrm{H}_{3}$ results in the protonolysis of two phosphinimines yielding neutral $\left[L^{\mathrm{Ad}} \mathrm{H}\right] \mathrm{Fe}$ (Scheme 1 ). 
Scheme 1. Synthesis of the described complexes.
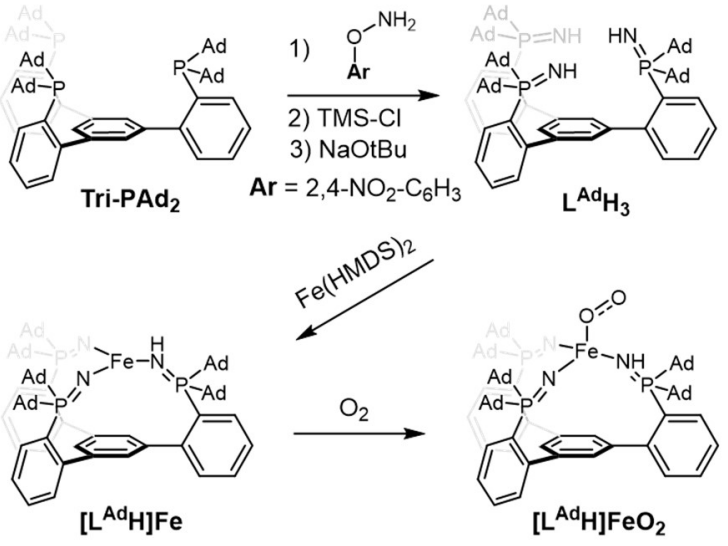

The solid-state structure of $\left[\mathrm{L}^{\mathrm{Ad}} \mathrm{H}\right] \mathrm{Fe}$ features a trigonal planar iron atom bound to two phosphinimides and one phosphinimine (Fig 1). Observed Fe-N bond distances coincide with the protonation state of each donor atom: the two Fe-N(phosphinimide) bond distances are 1.886(2) and 1.894(2) $\AA$ whereas the Fe-N(phosphinimine) bond distance is 2.074(2) $\AA$. The short Fe-N(phosphinimide) bond distances can be understood by the two canonical resonance forms of phosphinimide ligands (Scheme 2). Considering resonance form (B), terminal phosphinimide coordination to $\mathrm{Fe}$ allows for $\mathrm{Fe}-\mathrm{N} \sigma$-bonding and multiplanar $\mathrm{Fe}-\mathrm{N} \pi$-bonding. Such $\pi$-donation is expected to considerably raise the energy of the $d$-orbital manifold and stabilize high-spin ground states. Solution-phase magnetic measurements of this compound are consistent with an $S=2$ spin state ( $\mu_{\text {eff }}=4.94 \mu_{\mathrm{B}}$ ), as is typical for three-coordinate $\mathrm{Fe}^{11}$ compounds. ${ }^{20,21}$ Electrochemical experiments indicate that $\left[\mathrm{L}^{\mathrm{Ad}} \mathrm{H}\right] \mathrm{Fe}$ exhibits a quasireversible oxidation event at $-1.35 \mathrm{~V}$ in THF electrolyte (Fig S15), which is significantly more reducing than related trigonal, high-spin iron(II) complexes. ${ }^{22,23} \mathrm{We}$ hypothesize that the unusually low oxidation potential of $\left[\mathrm{L}^{\mathrm{Ad}} \mathrm{H}\right] \mathrm{Fe}$ is a testament to the $\pi$-donation presented by the terminally-bound phosphinimide ligands.

The $\left[\mathrm{L}^{\mathrm{Ad}} \mathrm{H}\right] \mathrm{Fe}$ compound reacts with $\mathrm{O}_{2}$ in crystallo to form a terminal $\mathrm{Fe}-\mathrm{O}_{2}$ complex, $\left[\mathrm{L}^{\mathrm{Ad}} \mathrm{H}\right] \mathrm{FeO}_{2}$. Yellow monoclinic crystals of $\left[\mathrm{L}^{\mathrm{Ad}} \mathrm{H}\right] \mathrm{Fe}$ visibly darken upon exposure to dry $\mathrm{O}_{2}$ and retain strong diffraction intensity to $\sim 0.8 \AA$. Subsequent XRD studies on such crystals indicate that a single $\mathrm{O}_{2}$ molecule has coordinated to the Fe center (Fig 1) which adopts a squashed-tetrahedral

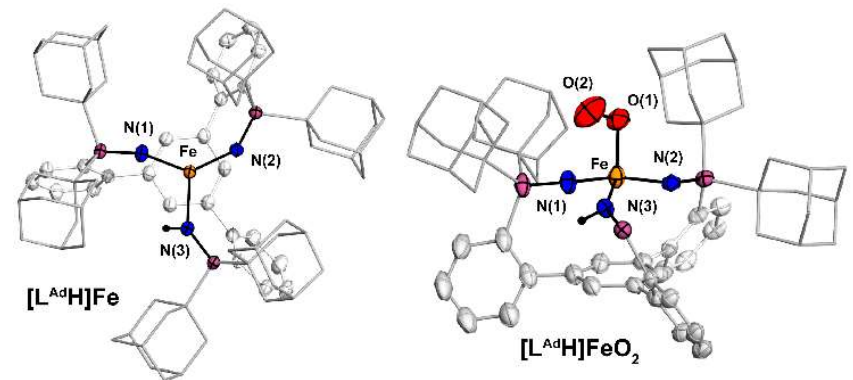

Figure 1. $X R D$ structures of [ $\left.\mathrm{L}^{\mathrm{Ad}} \mathrm{H}\right] \mathrm{Fe}$ (left) and $\left[\mathrm{L}^{\mathrm{Ad}} \mathrm{H}\right] \mathrm{FeO}_{2}$ (right). Thermal ellipsoids are drawn at $50 \%$ probability. Solvent molecules, disordered adamantyl substituents, and $\mathrm{C}-H$ bonds have been removed. Portions of the ligand framework are hidden for clarity.
Scheme 2. Phosphinimide resonance structures

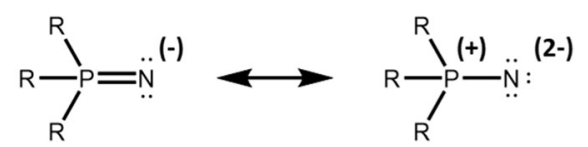

(A)

(B)

geometry $\left(\mathrm{THC}_{\mathrm{DA}}=0.55\right)^{24}$ in $\left[\mathrm{Ld}^{\mathrm{Ad}} \mathrm{H}\right] \mathrm{FeO}_{2}$. Despite the low coordination geometry at $\mathrm{Fe}$, the $\mathrm{O}_{2}$ ligand is bound in an ordered, terminal fashion with measured $\mathrm{Fe}-\mathrm{O}$ and $\mathrm{O}-\mathrm{O}$ bond distances of 1.981(3) and 1.321(5) $\AA$, respectively, and an $\mathrm{Fe}-\mathrm{O}-\mathrm{O}$ angle of $114.8(3)^{\circ}$. The observed $\mathrm{O}-\mathrm{O}$ distance implies an activated superoxide $\left(\mathrm{O}_{2}{ }^{-}\right)$ formulation. ${ }^{25}$ Marginally shorter average $\mathrm{Fe}$ $\mathrm{N}$ (phosphinimide) distances (1.87(2) $\AA$ ) in $\left[\mathrm{L}^{\mathrm{Ad}} \mathrm{H}\right] \mathrm{FeO}_{2}$ as compared to its precursor are also consistent with a more oxidized Fe center. To the best of our knowledge, this is the first crystallographically characterized, mononuclear non-heme iron-dioxygen complex obtained via addition of $\mathrm{O}_{2}$ to a synthetic $\mathrm{Fe}$ (II) compound. ${ }^{7,8}$ The terminal manner of $\mathrm{O}_{2}$ coordination and the experimentally determined structural metrics are comparable to those computationally predicted for the $\mathrm{Fe}-\mathrm{O}_{2}$ adducts in isopenicillin $\mathrm{N}$-synthase, ${ }^{5}$ homoprotocatechuate dioxgenase, ${ }^{4}$ and other non-heme iron oxygenases. ${ }^{26-28}$

Spectroscopic measurements support a high-spin $\mathrm{Fe}(\mathrm{III})$ center antiferromagnetically coupled to a superoxide ligand in $\left[\mathrm{L}^{\mathrm{Ad}} \mathrm{H}\right] \mathrm{FeO}{ }_{2}$. The ${ }^{57} \mathrm{Fe}$ Mössbauer spectrum of polycrystalline [ $\left.\mathrm{L}^{\mathrm{Ad}} \mathrm{H}\right] \mathrm{Fe}$ (Fig $2 \mathrm{~A}$ ) appears as a sharp quadrupole doublet with parameters $(\delta=0.59$ $\mathrm{mm} / \mathrm{s}, \Delta \mathrm{E}_{\mathrm{Q}}=1.45 \mathrm{~mm} / \mathrm{s}$ ) in line with those of other lowcoordinate, high-spin ferrous sites. ${ }^{23,29}$ A spectrum obtained on similarly-prepared $\left[\mathrm{L}^{\mathrm{Ad}} \mathrm{H}\right] \mathrm{Fe}$ material following $\mathrm{O}_{2}$ exposure displays a single, broad quadrupole doublet with parameters $\left(\delta=0.37 \mathrm{~m} / \mathrm{ms}, \Delta \mathrm{E}_{\mathrm{Q}}=1.32\right.$ $\mathrm{mm} / \mathrm{s}$ ) consistent with a high-spin $\mathrm{Fe}(\mathrm{III})$ center in $\left[\mathrm{L}^{\mathrm{Ad}} \mathrm{H}\right] \mathrm{FeO}_{2}{ }^{30}$ The large linewidth associated with this spectrum may be a consequence of slow electronic relaxation at $80 \mathrm{~K}$, as suggested by EPR measurements (vide infra).

Solution-phase magnetic measurements of $\left[\mathrm{L}^{\mathrm{Ad}} \mathrm{H}\right] \mathrm{Fe}$ recorded immediately after exposure to $\mathrm{O}_{2}$ indicate an apparent $S=2$ state for in situ-generated $\left[\mathrm{L}^{\mathrm{Ad}} \mathrm{H}\right] \mathrm{FeO}_{2}$ at room temperature ( $\mu_{\text {eff }}=4.9 \mu \mathrm{B}$ ). As previously discussed for other non-heme iron-dioxygen complexes, ${ }^{26-28,31}$ the

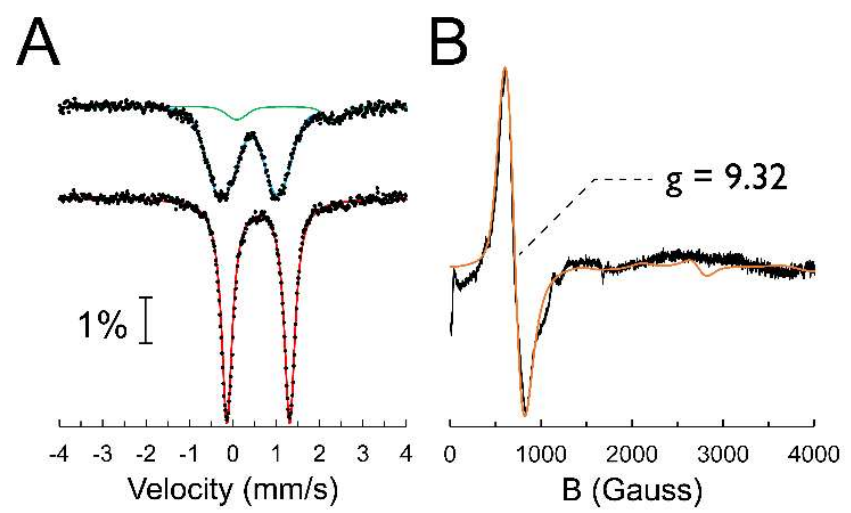

Figure 2. (A) Zero-field ${ }^{57} \mathrm{Fe}$ Mössbauer spectra of [ $\left.{ }^{\mathrm{Ad}} \mathrm{H}\right] \mathrm{Fe}$ (bottom) and [ $\left.{ }^{\mathrm{Ad}} \mathrm{H}\right] \mathrm{FeO}_{2}$ (top) collected at $80 \mathrm{~K}$. A $10 \%$ $\mathrm{Fe}(\mathrm{II})$ impurity (green) is observed in the $\left[\mathrm{LAd}^{\mathrm{Ad}} \mathrm{H}\right] \mathrm{FeO}_{2}$ sample. (B) Parallel-mode X-band EPR spectrum of a toluene solution of [ $\left.\mathrm{L}^{\mathrm{Ad}} \mathrm{H}\right] \mathrm{FeO}_{2}$ at $5 \mathrm{~K}$. 


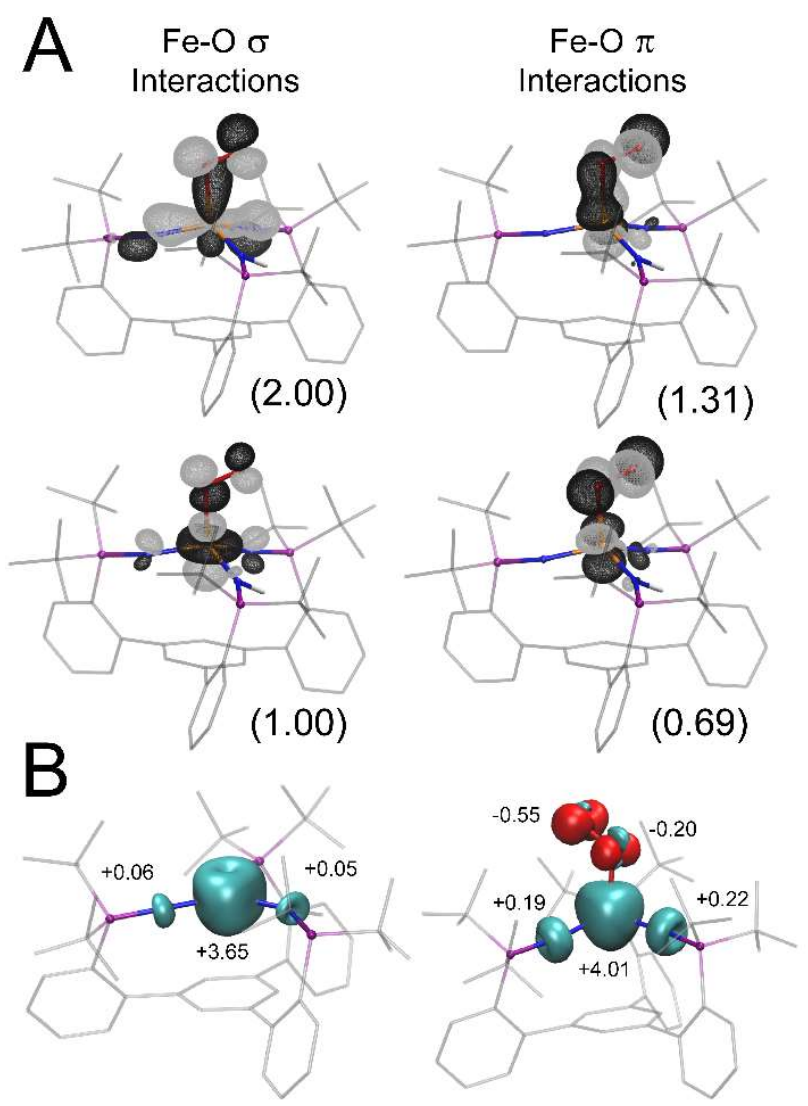

Figure 3. (A) Natural orbitals of $\left[\mathrm{L}^{t-\mathrm{Bu}} \mathrm{H}\right] \mathrm{FeO}_{2}$ constituting the $\mathrm{Fe}-\mathrm{O}$ bonding interactions. Electron occupancies are denoted underneath each orbital. (B) Spin density plots of $\left[\mathrm{L}^{t-\mathrm{Bu}} \mathrm{H}\right] \mathrm{Fe}$ (left) and [ $\left.{ }^{t-\mathrm{Bu}} \mathrm{H}\right] \mathrm{FeO}_{2}$ (right). Contour values are drawn at 0.05 and $0.01 \mathrm{e}^{-/} \AA^{3}$ for $A$ and $B$, respectively.

interaction of $\mathrm{O}_{2}$ with high-spin ferrous ions can give rise to $\mathrm{Fe}-\mathrm{O}_{2}$ complexes with total spin states $\left(S_{T O T}\right)$ of 1, 2 or 3. Similar total spin states can be envisioned for [ $\left.\mathrm{L}^{\mathrm{Ad}} \mathrm{H}\right] \mathrm{FeO}_{2}$, the relative energies of which dictate the observed Boltzmann distribution at elevated temperatures. Parallel mode $\mathrm{X}$-band EPR spectra of $\left[{ }^{\mathrm{Ad}} \mathrm{H}\right] \mathrm{FeO}_{2}$ at $5 \mathrm{~K}$ reveal an intense resonance at $g=$ 9.32. This feature can be observed at temperatures up to $65 \mathrm{~K}$ and no other resonances emerge over this temperature range. This feature can be comparably simulated using $S_{T O T}=2$ or 3 spin states attendant with rhombicity (E/D) values of 0.154 and 0.001 , respectively (Fig S6). We favor the $S_{T O T}=2$ simulation as $\left[\mathrm{L}^{\mathrm{Ad}} \mathrm{H}\right] \mathrm{FeO}$ should exhibit substantial rhombic character owing to a distorted tetrahedral Fe geometry and aspherical metalligand $\pi$-bonding interactions. ${ }^{32}$ Accordingly, we assign this feature to a transition within the $| \pm 2\rangle$ doublet for an $S$ $=2$ ground state that is energetically well-isolated. ${ }^{33}$

DFT methods provide further insight into the electronic structure of $\left[\mathrm{Ldd}^{\mathrm{Ad}} \mathrm{H}\right] \mathrm{FeO}_{2}$. Gas-phase geometry optimizations were performed on modestly truncated $\left[\mathrm{L}^{t-B u} \mathrm{H}\right] \mathrm{Fe}$ and $\left[\mathrm{L}^{t-B u} \mathrm{H}\right] \mathrm{FeO}_{2}$ using the TPSSh functional. ${ }^{34}$ Salient metrics found for gas-phase ${ }^{5}\left[\mathrm{~L}^{t-\mathrm{Bu} \mathrm{H}] \mathrm{FeO}_{2}}\right.$ specifically the Fe-N/O and $\mathrm{O}-\mathrm{O}$ bond distances, Fe-O-O angle and local $\mathrm{Fe}$ geometry - closely match the experimental values found for $\left[\mathrm{L}^{\mathrm{Ad}} \mathrm{H}\right] \mathrm{FeO}_{2}$ (Table S3). The natural orbitals constituting the $\mathrm{Fe}-\mathrm{O} \sigma$-interactions (Fig $3 \mathrm{~A}$ ) imply a delocalized 2-center-3-electron interaction of an $\mathrm{Fe}-d_{z}{ }^{2}$ orbital and an $\mathrm{O}-\mathrm{O} \pi^{*}$ orbital of the $\mathrm{O}_{2}$-derived ligand. By convention, this interaction implies a formal reduction of $\mathrm{O}_{2}$ to a $\mathrm{O}_{2}^{(-)}$state. In contrast, the $\mathrm{Fe}-\mathrm{O} \pi$ interactions constructed from the bonding and antibonding combinations of an $\mathrm{Fe}-d_{x z}$ orbital and the orthogonal $\mathrm{O}-\mathrm{O} \pi^{*}$ orbital exhibit non-integer electron occupancies. This situation implies a localized, antiferromagnetic interaction as the electron populations for these two orbitals sum to 2.0 electrons and they exhibit pronounced spatial overlap. ${ }^{35}$ The magnitude of the exchange coupling constant predicted for this interaction $\left(-58 \text { to }-136 \mathrm{~cm}^{-1}\right)^{36}$ corroborates a well-isolated ground spin state. Considering the three additional, singlyoccupied orbitals (Fig S23), the electronic structure of ${ }^{5}\left[\mathrm{~L}^{t-\mathrm{Bu}} \mathrm{H}\right] \mathrm{FeO}_{2}$ is best described as an $S=5 / 2 \mathrm{Fe}(\mathrm{III})$ center antiferromagnetically coupled to an $S=1 / 2 \mathrm{O}_{2}^{-}$ligand.

These computational studies also aid in rationalizing the apparent stability of $\left[\mathrm{Ld}^{\mathrm{Ad}} \mathrm{H}\right] \mathrm{FeO}_{2}$. The spin density plot for ${ }^{5}\left[\mathrm{~L}^{t-\mathrm{Bu}} \mathrm{H}\right] \mathrm{Fe}$ (Fig 3B) illustrates that the Fe center bears the majority of the unpaired electron density $(+3.65$ electrons) with minimal spin leakage onto the two phosphinimide nitrogen atoms $(+0.11$ electrons total). In contrast, the spin density profile of ${ }^{5}\left[\mathrm{~L}^{t-\mathrm{Bu}} \mathrm{H}\right] \mathrm{FeO}_{2}$ reveals substantial unpaired spin density on both the phosphinimide $\mathrm{N}$-atoms ( 0.41 electrons total). Hence, electron density is mutually transferred from the Fe center and the supporting phosphinimides to $\mathrm{O}_{2}$ upon its coordination. The cylindrical distribution of electron density on the $\mathrm{N}$-atoms in ${ }^{5}\left[\mathrm{~L}^{t-\mathrm{Bu}} \mathrm{H}\right] \mathrm{FeO}_{2}$ evidences $\mathrm{Fe}-\mathrm{N}$ $\pi$-bonding interactions in two orthogonal planes. This situation contrasts that found for ligands commonly used to stabilize $\mathrm{FeO}_{x}$ species, such as porphyrin or amido-type $\left(\mathrm{R}_{2} \mathrm{~N}^{-}\right)$donors, that are restricted to forming $\mathrm{Fe}-\mathrm{N} \pi$-bonds in a single orientation. ${ }^{30,37,38}$ We hypothesize that the unique $\pi$-bonding characteristics of the $\left[\mathrm{L}^{\mathrm{Ad}} \mathrm{H}\right]^{2-}$ ligand serves to stabilize oxidized forms of bound metal ions, and in this case enables the robust coordination of $\mathrm{O}_{2}$ to Fe.

The $\left[\mathrm{L}^{\mathrm{Ad}} \mathrm{H}\right] \mathrm{Fe}$ platform engages in a range of oxidation reactions that proceed in stoichiometric and catalytic fashion. For example, [ $\left.\mathrm{L}^{\mathrm{Ad}} \mathrm{H}\right] \mathrm{Fe}$ catalyzes the $\mathrm{O}_{2-}$ mediated conversion of 1,2-diphenylhydrazine to azobenzene (Fig 4A). The reaction rate observed with deuterium labeled substrate implies a kinetic isotope effect of 2.90, consistent with a rate-determining
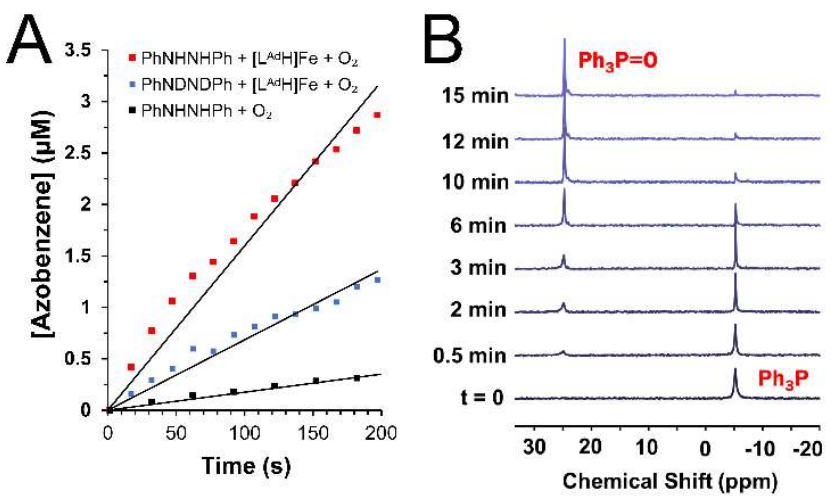

Figure 4. (A) Generation of azobenzene from 1,2diphenylhydrazine (red) or $d_{2}$-1,2-diphenylhydrazine (blue) in the presence of $\left[\mathrm{L}^{\mathrm{Ad}} \mathrm{H}\right] \mathrm{Fe}$ and $1 \mathrm{~atm} \mathrm{O}$ at rt. $(\mathrm{B}){ }^{31} \mathrm{P}\left\{{ }^{1} \mathrm{H}\right\}$ NMR spectra illustrating the rt conversion of $\mathrm{Ph}_{3} \mathrm{P}$ to $\mathrm{Ph}_{3} \mathrm{P}=\mathrm{O}$ mediated by $\left[\mathrm{L}^{\mathrm{Ad}} \mathrm{H}\right] \mathrm{Fe}$ under $1 \mathrm{~atm} \mathrm{O}_{2}$. 
hydrogen atom abstraction step that is presumably mediated by in-situ generated $\left[\mathrm{Ldd}^{\mathrm{Ad}} \mathrm{H}\right] \mathrm{FeO}_{2}$. In addition, the ability of [ $\left.\mathrm{L}^{\mathrm{Ad}} \mathrm{H}\right] \mathrm{Fe}$ to quantitatively convert 1 equiv of $\mathrm{PPh}_{3}$ to $\mathrm{O}=\mathrm{PPh}_{3}$ over $\sim 15$ minutes under an $\mathrm{O}_{2}$ atmosphere (Fig 4B) supports the generation of a reactive, electrophilic oxidant. ${ }^{39}$ The nature of the Fe-containing $\left[\mathrm{L}^{\mathrm{Ad}} \mathrm{H}\right] \mathrm{Fe}$-derived product(s) of these reactions are presently unknown and their characterization will be disclosed in a later report.

Finally, the $\left[\mathrm{L}^{\mathrm{Ad}} \mathrm{H}\right] \mathrm{Fe}$ complex was found to catalyze $\mathrm{C}-\mathrm{C}$ and $\mathrm{C}-\mathrm{H}$ bond cleavage processes. Inspired by previous reports of nucleophilic metal-dioxygen species that engage in aldehyde deformylation,,${ }^{740-45}$ we examined the reactivity of $\left[\mathrm{L}^{\mathrm{Ad}} \mathrm{H}\right] \mathrm{Fe}$ and 2-PPA in the presence of $\mathrm{O}_{2}$. Exposure of a 1:1 mixture of [ $\left[{ }^{A d} \mathrm{H}\right] \mathrm{Fe}$ and 2-PPA to $\mathrm{O}_{2}$ resulted in the formation of acetophenone in $>95 \%$ NMR yield. The identity of the other organic product was confirmed to be formic acid (Fig S2). Realizing that a full equivalent of dioxygen had been transferred to the substrate, we postulated that $\left[\mathrm{L}^{\mathrm{Ad}} \mathrm{H}\right] \mathrm{Fe}$ could be regenerated upon deprotonation of the formic acid. Under ideal conditions that employ TBD as a base, 18 equiv of acetophenone are produced at $5 \mathrm{~mol} \%$ [ [ $\left.{ }^{\mathrm{Ad}} \mathrm{H}\right] \mathrm{Fe}$ catalyst loading (Table 1). The direct usage of $\mathrm{O}_{2}$ as an oxidant here is unusual, ${ }^{42,45}$ and underscores the promising oxidation chemistry of the $\left[\mathrm{L}^{\mathrm{Ad}} \mathrm{H}\right] \mathrm{Fe}$ system.

Table 1. [ $\left.{ }^{A d} \mathrm{H}\right] \mathrm{Fe}$-catalyzed aldehyde deformylation

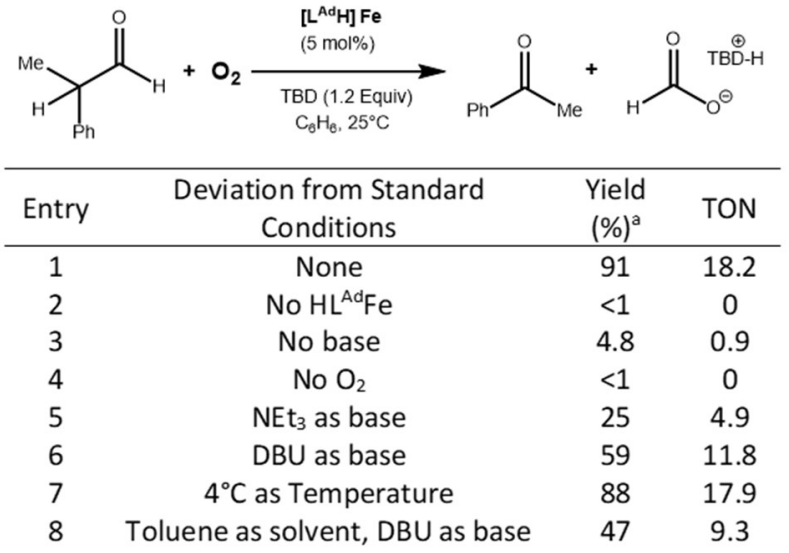

aThe yields were determined through ${ }^{1} \mathrm{H}$ NMR analysis with the aid of an internal standard $-1,3,5-(\mathrm{MeO})_{3} \mathrm{C}_{6} \mathrm{H}_{3}$ (average of two experiments).

\section{Conclusions}

In summary, a non-heme $\mathrm{Fe}-\mathrm{O}_{2}$ complex has been prepared via exposure of $\mathrm{O}_{2}$ to a phosphinimide-iron(II) compound. Its structural and spectroscopic features corroborate an antiferromagnetically-coupled, high-spin $\mathrm{Fe}(\mathrm{III})$-superoxide site analogous to that predicted for many non-heme iron oxygenase enzymes. This amphoteric oxidant engages in both $\mathrm{H}$ - and $\mathrm{O}$-atom transfer reactivity in addition to catalyzing oxidative aldehyde deformylation. These combined results demonstrate the utility in using phosphinimide ligands to simultaneously stabilize and harness reactive inorganic species. Further investigations aimed at probing the nature of the Fe-containing intermediates of these transformations are currently underway.

\section{ASSOCIATED CONTENT}

Experimental procedures, spectra and characterization data. This material is available free of charge via the Internet at http://pubs.acs.org.

\section{AUTHOR INFORMATION}

Corresponding Author

Jonathan Rittle - [0000-0001-6241-6253];

Email: rittle@berkeley.edu

Authors

Charles Winslow - [0000-0002-9296-1567]

Heui Beom Lee - [0000-0002-9550-2649]

Simon J. Teat - [0000-0001-9515-2602]

Notes

The authors declare no competing financial interest.

\section{ACKNOWLEDGMENT}

This research was supported by the University of California Berkeley. X-ray diffraction experiments performed at beamline 12.2.1 at the Advanced Light Source at Lawrence Berkeley National Laboratory were supported by the Director, Office of Science, Office of Basic Energy Sciences, of the U.S. Department of Energy under Contract No. DE-AC0205CH11231. We thank Prof Michael T. Green for access to a Mössbauer spectrometer, Prof R. David Britt and Dr. David Marchiori for access to and assistance with their EPR spectrometer (supported by NIH R35 Grant 1R35GM126961-01, to R.D.B. We thank Drs. Hasan Celik, Alicia Lund, and UC Berkeley's NMR facility in the College of Chemistry (CoC-NMR) for spectroscopic assistance. Instruments in the CoC-NMR are supported in part by $\mathrm{NIH}$ S100D024998. M.J.F. was supported by a National Sciences and Engineering Research Council of Canada (NSERC) Postgraduate Scholarship.

\section{ABBREVIATIONS}

1,5,7-triazabicyclodecene (TBD)

1,8-Diazabicyclo(5.4.0)undec-7-ene (DBU)

2-Phenylpropionaldehyde (2-PPA)

Density Functional Theory (DFT)

Electronic Paramagnetic Resonance (EPR)

Hexamethyldisilazide (HMDS)

Nuclear Magnetic Resonance (NMR)

Triethylamine (NEt 3 )

Turnover Number (TON)

X-Ray Diffraction (XRD)

\section{REFERENCES}

(1) Shi, Z.; Zhang, C.; Tang, C.; Jiao, N. Recent Advances in Transition-Metal Catalyzed Reactions Using Molecular Oxygen as the Oxidant. Chem. Soc. Rev. 2012, 41 (8), 3381-3430. https://doi.org/10.1039/c2cs15224j.

(2) Costas, M.; Mehn, M. P.; Jensen, M. P.; Que, L. Dioxygen Activation at Mononuclear Nonheme Iron Active Sites: Enzymes, Models, and Intermediates. Chem. Rev. 2004, 104 (2), 939-986. https://doi.org/10.1021/cr020628n.

(3) Peck, S. C.; van der Donk, W. A. Go It Alone: FourElectron Oxidations by Mononuclear Non-Heme Iron Enzymes. $J$. Biol. Inorg. Chem. 2017, 22 (2-3), 381-394. https://doi.org/10.1007/s00775-016-1399-y.

(4) Mbughuni, M. M.; Chakrabarti, M.; Hayden, J. A.; Bominaar, E. L.; Hendrich, M. P.; Münck, E.; Lipscomb, J. D. Trapping and Spectroscopic Characterization of an Felll-Superoxo Intermediate from a Nonheme Mononuclear Iron-Containing 
Enzyme. Proc. Natl. Acad. Sci. U. S. A. 2010, 107 (39), 1678816793. https://doi.org/10.1073/pnas.1010015107.

(5) Tamanaha, E.; Zhang, B.; Guo, Y.; Chang, W. C.; Barr, E. W.; Xing, G.; St Clair, J.; Ye, S.; Neese, F.; Bollinger, J. M.; Krebs, C. Spectroscopic Evidence for the Two C-H-Cleaving Intermediates of Aspergillus Nidulans Isopenicillin N Synthase. J. Am. Chem. Soc. 2016, 138 (28), 8862-8874. https://doi.org/10.1021/jacs.6b04065.

(6) Karlsson, A.; Parales, J. V.; Parales, R. E.; Gibson, D. T.; Eklund, H.; Ramaswamy, S. Crystal Structure of Naphthalene Dioxygenase: Side-on Binding of Dioxygen to Iron. Science 2003, 299 (5609), 1039-1042. https://doi.org/10.1126/science.1078020.

(7) Hong, S.; Sutherlin, K. D.; Park, J.; Kwon, E.; Siegler, M. A.; Solomon, E. I.; Nam, W. Crystallographic and Spectroscopic Characterization and Reactivities of a Mononuclear Non-Haem Iron(III)-Superoxo Complex. Nat. Commun. 2014, 5. https://doi.org/10.1038/ncomms6440.

(8) Chiang, C. W.; Kleespies, S. T.; Stout, H. D.; Meier, K. K.; Li, P. Y.; Bominaar, E. L.; Que, L.; Münck, E.; Lee, W. Z. Characterization of a Paramagnetic Mononuclear Nonheme IronSuperoxo Complex. J. Am. Chem. Soc. 2014, 136 (31), 1084610849. https://doi.org/10.1021/ja504410s.

(9) Blakely, M. N.; Dedushko, M. A.; Yan Poon, P. C.; VillarAcevedo, G.; Kovacs, J. A. Formation of a Reactive, Alkyl ThiolateLigated Fe III -Superoxo Intermediate Derived from Dioxygen. J. Am. Chem. Soc. 2019, 141 (5), 1867-1870. https://doi.org/10.1021/jacs.8b12670.

(10) Oloo, W. N.; Que, L. Bioinspired Nonheme Iron Catalysts for $\mathrm{C}-\mathrm{H}$ and $\mathrm{C}=\mathrm{C}$ Bond Oxidation: Insights into the Nature of the Metal-Based Oxidants. Acc. Chem. Res. 2015, 48 (9), 2612-2621. https://doi.org/10.1021/acs.accounts.5b00053.

(11) Collins, T. J. TAML Oxidant Activators: A New Approach to the Activation of Hydrogen Peroxide for Environmentally Significant Problems. Acc. Chem. Res. 2002, 35 (9), 782-790. https://doi.org/10.1021/ar010079s.

(12) White, M. C.; Doyle, A. G.; Jacobsen, E. N.; Har, V.; Uni, V.; March, R. V. System A Synthetically Useful , Self-Assembling MMO Mimic System for Catalytic Alkene Epoxidation with Aqueous $\mathrm{H}_{2} \mathrm{O}_{2}$. J. Am. Chem. Soc. 2001, 2, 7194-7195.

(13) Chen, M. S.; White, M. C. Combined Effects on Selectivity in Fe-Catalyzed Methylene Oxidation. Science 2010, 327 (5965), 566 - 571. https://doi.org/10.1126/science.1183602.

(14) Lee, H. B.; Ciolkowski, N.; Winslow, C.; Rittle, J. Submitted.

(15) Dehnicke, K.; Krieger, M.; Massa, W. Phosphoraneiminato Complexes of Transition Metals. Coord. Chem. Rev. 1999, 182 (1), 19-65. https://doi.org/10.1016/S0010-8545(98)00191-X.

(16) Stephan, D. W. Phosphinimides as a Steric Equivalent to Cyclopentadienyl: An Approach to Ethylene Polymerization Catalyst Design. Organometallics 1999, 18 (7), 1116-1118. https://doi.org/10.1021/om980955e.

(17) Rice, N. T.; Popov, I. A.; Russo, D. R.; Bacsa, J.; Batista, E. R.; Yang, P.; Telser, J.; La Pierre, H. S. Design, Isolation, and Spectroscopic Analysis of a Tetravalent Terbium Complex. J. Am. Chem. Soc. 2019, 141 (33), 13222-13233. https://doi.org/10.1021/jacs.9b06622.

(18) Scepaniak, J. J.; Harris, T. D.; Vogel, C. S.; Sutter, J.; Meyer, K.; Smith, J. M. Spin Crossover in a Four-Coordinate Iron(II) Complex. J. Am. Chem. Soc. 2011, 133 (11), 3824-3827. https://doi.org/10.1021/ja2003473.

(19) Camacho-Bunquin, J.; Ferguson, M. J.; Stryker, J. M. Hydrocarbon-Soluble Nanocatalysts with No Bulk Phase: Coplanar, Two-Coordinate Arrays of the Base Metals. J. Am. Chem. Soc. 2013 135 (15), 5537-5540. https://doi.org/10.1021/ja401579x.

(20) Eckert, N. A.; Smith, J. M.; Lachicotte, R. J.; Holland, P. L. Low-Coordinate Iron(II) Amido Complexes of $\beta$-Diketiminates: Synthesis, Structure, and Reactivity. Inorg. Chem. 2004, 43 (10), 3306-3321. https://doi.org/10.1021/ic035483x.

(21) Maddock, L. C. H.; Cadenbach, T.; Kennedy, A. R.; Borilovic, I.; Aromí, G.; Hevia, E. Accessing Sodium Ferrate Complexes Containing Neutral and Anionic N-Heterocyclic Carbene
Ligands: Structural, Synthetic, and Magnetic Insights. Inorg. Chem 2015, 54 (18), 9201-9210. https://doi.org/10.1021/acs.inorgchem.5b01638.

(22) Margraf, G.; Schödel, F.; Sänger, I.; Bolte, M.; Wagner, M.; Lerner, H. W. An Electrochemical and Structural Study of the Iron Silylamides Fe[N( $\left.\left.\mathrm{SiMe}_{3}\right)_{2}\right]_{2}$ And. Zeitschrift fur Naturforsch. - Sect. B J. Chem. Sci. 2012, $67 \quad$ (6), 549-556. https://doi.org/10.5560/znb.2012-0060.

(23) Sazama, G. T.; Betley, T. A. Ligand-Centered Redox Activity: Redox Properties of 3d Transition Metal lons Ligated by the Weak-Field Tris(Pyrrolyl)Ethane Trianion. Inorg. Chem. 2010, 49 (5), 2512-2524. https://doi.org/10.1021/ic100028y.

(24) Höpfl, H. The Tetrahedral Character of the Boron Atom Newly Defined - A Useful Tool to Evaluate the $\mathrm{N} \rightarrow$ B Bond. J. Organomet. Chem. 1999, 581 (1-2), 129-149. https://doi.org/10.1016/S0022-328X(99)00053-4.

(25) Abrahams, S. C.; Kalnajs, J. The Crystal Structure of aPotassium Superoxide. Acta Crystallogr. 1955, 8 (8), 503-506. https://doi.org/10.1107/s0365110x55001540.

(26) Kumar, D.; Thiel, W.; De Visser, S. P. Theoretical Study on the Mechanism of the Oxygen Activation Process in Cysteine Dioxygenase Enzymes. J. Am. Chem. Soc. 2011, 133 (11), 38693882. https://doi.org/10.1021/ja107514f

(27) Bassan, A.; Borowski, T.; Siegbahn, P. E. M. Quantum Chemical Studies of Dioxygen Activation by Mononuclear NonHeme Iron Enzymes with the 2-His-1-Carboxylate Facial Triad. Dalt. Trans. 2004, No. 20, 3153-3162. https://doi.org/10.1039/b408340g.

(28) Ye, S.; Riplinger, C.; Hansen, A.; Krebs, C.; Bollinger, J. M.; Neese, F. Electronic Structure Analysis of the Oxygen-Activation Mechanism by $\mathrm{Fe}$ II- and a-Ketoglutarate (AKG)-Dependent Dioxygenases. Chem. - A Eur. J. 2012, 18 (21), 6555-6567. https://doi.org/10.1002/chem.201102829.

(29) Macdonnell, F. M.; Ruhlandt-senge, K.; Ellison, J. J.; Holm, R. H.; Power, P. P. Sterically Encumbered Iron (II) Thiolate Complexes: Synthesis and Structure of Trigonal. 1995, 34 (7), 1815-1822.

(30) MacBeth, C. E.; Golombek, A. P.; Young, J.; Yang, C.; Kuczera, K.; Hendrich, M. P.; Borovik, A. S. O2 Activation by Nonheme Iron Complexes: A Monomeric Fe(III)-Oxo Complex Derived from O2. Science 2000, 289 (5481), 938-941. https://doi.org/10.1126/science.289.5481.938.

(31) Stout, H. D.; Kleespies, S. T.; Chiang, C. W.; Lee, W. Z.; Que, L.; Münck, E.; Bominaar, E. L. Spectroscopic and Theoretical Study of Spin-Dependent Electron Transfer in an Iron(III) Superoxo Complex. Inorg. Chem. 2016, 55 (11), 5215-5226. https://doi.org/10.1021/acs.inorgchem.6b00134.

(32) Sazama, G. T.; Betley, T. A. Multiple, Disparate Redox Pathways Exhibited by a Tris(Pyrrolido)Ethane Iron Complex. Inorg Chem. 2014, 53 (1), 269-281. https://doi.org/10.1021/ic402210j.

(33) Kostka, K. L.; Fox, B. G.; Hendrich, M. P.; Collins, T. J.; Rickard, C. E. F.; Wright, L. J.; Munck, E. High-Valent Transition Metal Chemistry. Moessbauer and EPR Studies of High-Spin ( $\mathrm{S}=2)$ Iron(IV) and Intermediate-Spin (S = 3/2) Iron(III) Complexes with a Macrocyclic Tetraamido-N Ligand. J. Am. Chem. Soc. 1993, 115 (15), 6746-6757. https://doi.org/10.1021/ja00068a035.

(34) Jensen, K. P. Bioinorganic Chemistry Modeled with the TPSSh Density Functional. Inorg. Chem. 2008, 47 (22), 1035710365. https://doi.org/10.1021/ic800841t.

(35) Green, M. T. Evidence for Sulfur-Based Radicals in Thiolate Compound I Intermediates [5]. J. Am. Chem. Soc. 1999, 121 (34), 7939-7940. https://doi.org/10.1021/ja991541v.

(36) Tomson, N. C.; Crimmin, M. R.; Petrenko, T.; Rosebrugh, L. E.; Sproules, S.; Christopher Boyd, W.; Bergman, R. G.; Debeer S.; Dean Toste, F.; Wieghardt, K. A Step beyond the FelthamEnemark Notation: Spectroscopic and Correlated Ab Initio Computational Support for an Antiferromagnetically Coupled M(II)(NO)- Description of Tp*M(NO) (M = Co, Ni). J. Am. Chem. Soc 2011, 133 (46), 18785-18801. https://doi.org/10.1021/ja206042k.

(37) Schappacher, M.; Weiss, R.; Montiel-Montoya, R.; Trautwein, A.; Tabard, A. Formation of an Iron(IV)-Oxo "Picket- 
Fence" Porphyrin Derivative via Reduction of the Ferrous Dioxygen Adduct and Reaction with Carbon Dioxide. J. Am. Chem. Soc. 1985, 107 (12), 3736-3738. https://doi.org/10.1021/ja00298a065.

(38) De Oliveira, F. T.; Chanda, A.; Banerjee, D.; Shan, X.; Mondal, S.; Que, L.; Bominaar, E. L.; Münck, E.; Collins, T. J. Chemical and Spectroscopic Evidence for an $\mathrm{Fe}^{\mathrm{V}}$-Oxo Complex. Science 2007, 315 (5813), 835-838. https://doi.org/10.1126/science.1133417.

(39) Cho, J.; Woo, J.; Nam, W. A Chromium(III)-Superoxo Complex in Oxygen Atom Transfer Reactions as a Chemical Model of Cysteine Dioxygenase. J. Am. Chem. Soc. 2012, 134 (27), 1111211115. https://doi.org/10.1021/ja304357z.

(40) Wertz, D. L.; Valentine, J. S. Nucleophilicity of Iron-Peroxo Porphyrin Complexes. In Metal-Oxo and Metal-Peroxo Species in Catalytic Oxidations; Meunier, B., Ed.; Springer Berlin Heidelberg: Berlin, Heidelberg, 2000; pp 37-60. https://doi.org/10.1007/3-54046592-8 2 .

(41) Shokri, A.; Que, L. Conversion of Aldehyde to Alkane by a Peroxoiron(III) Complex: A Functional Model for the Cyanobacterial Aldehyde-Deformylating Oxygenase. J. Am. Chem. Soc. 2015, 137 (24), 7686-7691. https://doi.org/10.1021/jacs.5b01053.
(42) Annaraj, J.; Suh, Y.; Seo, M. S.; Kim, S. O.; Nam, W. Mononuclear Nonheme Ferric-Peroxo Complex in Aldehyde Deformylation. Chem. Commun. 2005, No. 36, 4529-4531. https://doi.org/10.1039/b505562h.

(43) Lin, Y. H.; Kutin, Y.; Van Gastel, M.; Bill, E.; Schnegg, A.; Ye, S.; Lee, W. Z. A Manganese(IV)-Hydroperoxo Intermediate Generated by Protonation of the Corresponding Manganese(III)Superoxo Complex. J. Am. Chem. Soc. 2020, 142 (23), 1025510260. https://doi.org/10.1021/jacs.0c02756.

(44) Cho, J.; Sarangi, R.; Annaraj, J.; Kim, S. Y.; Kubo, M.; Ogura, T.; Solomon, E. I.; Nam, W. Geometric and Electronic Structure and Reactivity of a Mononuclear Side-on Nickel(lii)-Peroxo Complex. Nat. Chem. 2009, 1 (7), 568-572. https://doi.org/10.1038/nchem.366.

(45) Corcos, A. R.; Villanueva, O.; Walroth, R. C.; Sharma, S. K.; Bacsa, J.; Lancaster, K. M.; MacBeth, C. E.; Berry, J. F. Oxygen Activation by $\mathrm{Co}(\mathrm{II})$ and a Redox Non-Innocent Ligand: Spectroscopic Characterization of a Radical-Co(II)-Superoxide Complex with Divergent Catalytic Reactivity. J. Am. Chem. Soc. 2016, 138 (6), 1796-1799. https://doi.org/10.1021/jacs.5b12643. 
Table of Contents Graphic

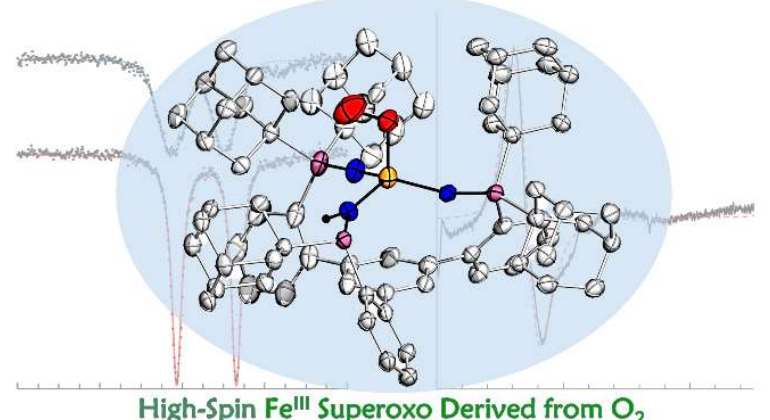

High-Spin Fe III Superoxo Derived from $\mathrm{O}_{2}$ 